\title{
Correction to: Bringing the Neighbourhood Into Urban Infill Development in the Interest of Well-Being
}

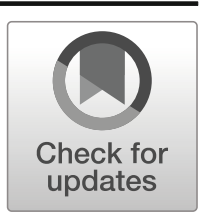

\section{Meg Holden ${ }^{1}$}

Published online: 28 March 2019

(C) Springer Nature Switzerland AG 2019

\section{Correction to: International Journal of Community Well-Being https://doi.org/10.1007/s42413-018-0010-4}

\section{Acknowledgements}

The author gratefully acknowledges the financial support of the Bullitt Foundation and partnership with Small Housing BC that gave rise to the research reported here. Hamidreza Bakhtiarizadeh and Alex Thumm supported survey research analysis. Erick Villagomez supported the graphics and design. Mustel Group implemented the resident survey.

The original article has been updated.

Publisher's Note Springer Nature remains neutral with regard to jurisdictional claims in published maps and institutional affiliations.

The online version of the original article can be found at https://doi.org/10.1007/s42413-018-0010-4

Meg Holden

mholden@sfu.ca

1 Urban Studies and Geography, Simon Fraser University, 2nd Floor, 515 W. Hastings St., Vancouver, BC V6B 5K3, Canada 